\title{
Racial differences in child safety restraint use in Tennessee
}

\author{
V L Gunn, R M Phillippi, W O Cooper
}

Injury Prevention 2005;11:340-342. doi: 10.1136/ip.2005.008706

\begin{abstract}
Objectives: To evaluate the appropriate use of child safety restraints (CSR) in black and white children.

Design: Cross sectional, observational study of drivers of children age $0-10$ years involving an on-site vehicle and CSR inspection and brief driver interview.

Results: Data were obtained on 244 white and 204 black children; results were stratified by race due to effect modification of race on driver restraint use and CSR use. Twenty four percent of black and 13\% of white child passengers aged 4-10 years were completely unrestrained $(p=0.003)$. Of the 168 black and 220 white child passengers aged $0-10$ years who were restrained, $64 \%$ of black and $58 \%$ of white children had inappropriate restraint use. Appropriate CSR use was significantly lower in 4-8 year old passengers compared with appropriately restrained children aged $<4$ years and 9-10 years $(p<0.0001$ for both black and white child passengers).

Conclusions: Black child passengers and all child passengers aged 4-8 years are at increased risk of being inappropriately restrained. Educational efforts should address specific barriers to booster seat use in these populations.
\end{abstract}

lea njuries sustained in motor vehicle crashes remain the leading cause of morbidity and mortality for US children older than 1 year of age. ${ }^{12}$ Of children killed in motor vehicle crashes, 50\% are unrestrained. ${ }^{1}$ Black children are at particularly high risk of morbidity and mortality from motor vehicle crashes, ${ }^{3}{ }^{4}$ presumably due to low rates of restraint use, ${ }^{4}$ however, little is known about the overall frequency of appropriate child safety restraint use in black children. The purpose of this study was to evaluate the appropriate use of child safety restraints in black and white children in three urban communities in Tennessee.

\section{METHODS}

From April to June, 2004, we conducted a cross sectional, observational study of drivers of children 0-10 years of age involving an on-site vehicle and child safety restraint (CSR) inspection and brief driver interview.

The assessment tool was adapted from a previously studied traffic survey. ${ }^{5}$ Data collected included both observed (driver seat belt use, seating position of children, and restraint type) and self-reported information (child race, sex, age, weight, and height, and driver race). Drivers of inappropriately restrained and unrestrained child passengers 4-8 years of age were asked to identify barriers to booster seat use.

Before the study, regional study coordinators were sent copies of the assessment tool, written instructions with scripted questions, and photographs of various CSR types. Each new assessor completed a "practice" assessment before data collection which was reviewed by the study coordinator. All study coordinators were certified Child Passenger Safety Technicians.
Schools and summer programs representing geographic and income diversity in three urban counties in Tennessee were randomly selected for participation. The drivers of all vehicles entering or leaving the study site were approached, and consent to participate in the study was obtained from each driver before data collection. No data were collected on vehicles when the driver declined to participate. Approximately $80 \%$ of drivers approached agreed to participate.

Any use of CSRs was defined as the child passenger secured in any form of restraint device. Appropriate use of CSRs was determined using Tennessee law which requires rear facing CSR for children younger than one year or less than $20 \mathrm{lb}$; forward facing CSR for children $1-3$ years and weighing more than $20 \mathrm{lb}$; belt positioning booster seats for children 4-8 years and less than 57 inches in height; and seat belts for children 9-16 years and adults. ${ }^{6}$ Poisson regression with robust standard errors was used to model appropriate CSR use, accounting for clustering of children by vehicle. Approval for the study was obtained from the Institutional Review Board of Vanderbilt University prior to implementation.

\section{RESULTS}

Data were collected on 244 white and 204 black children who were 0-10 years of age and transported in 432 vehicles at 18 assessment sites. In all cases, the race of the driver and the child passenger was the same. Black and white child passengers had similar age distributions with approximately $23 \%<4$ years, $60 \% 4-8$ years, and $16 \% 9-10$ years (table 1 ).

Twenty four percent of black and 13\% of white child passengers 4-10 years were completely unrestrained $(\mathrm{p}=0.003)$. Of the 168 black and 220 white child passengers 0-10 years who were restrained, $64 \%$ of black and $58 \%$ of white children had inappropriate restraint use. All children younger than 4 years of age, and most children $>4$ years were in some form of restraint. However, appropriate CSR use was lower in black and white children in all age groups. Appropriate CSR use was significantly lower in $4-8$ year old passengers compared to appropriately restrained children $<4$ years and $9-10$ years $(\mathrm{p}<0.0001$ for both black and white child passengers).

Driver restraint use was significantly associated with any and appropriate CSR use for blacks and whites (table 2).

We asked drivers of children 4-8 years old who were not in booster seats to identify barriers to booster seat use. More white drivers (76\%) than black drivers (49\%) felt their child was too large for a booster seat $(\mathrm{p}=0.002)$. This perception was accurate for only $2 \%$ of white and black children aged 4-8 years; however, $60 \%$ of these children for whom this perception was accurate were unrestrained. More black drivers $(25 \%)$ than white drivers (14\%) did not know the child needed to be in a booster seat. No white drivers and $4 \%$ of black drivers stated that the child was not restrained because they could not afford a booster seat (see fig 1).

Abbreviation: CSR, child safety restraint 


\begin{tabular}{|c|c|c|}
\hline Characteristic & White & lBlack \\
\hline Male child, $\mathrm{n}(\%)^{*}$ & $99(46)$ & $91(51)$ \\
\hline \multicolumn{3}{|c|}{ Child passengers, $n$ (\% any restraint) } \\
\hline$<4$ years & $55(100)$ & $51(100)$ \\
\hline $4-8$ years & $152(88)$ & $117(72)$ \\
\hline $9-10$ years & $37(84)$ & $36(92)$ \\
\hline \multicolumn{3}{|c|}{$\begin{array}{l}\text { Appropriately restrained child passengers, } \mathrm{n} \\
(\%)\end{array}$} \\
\hline$<4$ years & $46(84)$ & $42(82)$ \\
\hline $4-8$ years & $43(28)$ & $25(21)$ \\
\hline 9-10 years & $28(76)$ & $30(83)$ \\
\hline Driver, $\mathrm{n}$ (\% restrained) & $191(80)$ & 150 (77) \\
\hline
\end{tabular}

${ }^{*}$ Sex was not recorded for all child passengers.

\section{DISCUSSION}

This study revealed that more black (24\%) than white (13\%) child passengers were completely unrestrained $(p=0.003)$. This reflects decreased uptake of CSR use among black children, despite national improvements in driver restraint use by black adults. ${ }^{78}$ The lack of appropriate restraint use among black child passengers may reflect drivers' diminished risk perceptions regarding the likelihood of having a collision, or of the child passenger sustaining an injury without the use of CSRs.'

Booster eligible children ages 4-8 years were also at increased risk of being inappropriately restrained. This has been noted in previous studies and may reflect a lack of knowledge about the need for booster seats and the age and weight requirements for use. Most drivers of 4-8 year olds who were not in a booster seat believed that the child was too large for a booster seat; however this perception was accurate for only $2 \%$ of $4-8$ year olds. Nearly twice as many black as white drivers cited a lack of knowledge of the need for booster seat use. This difference in knowledge may indicate that educational efforts regarding booster seats do not reach all intended audiences. ${ }^{10}{ }^{11}$ Although cost of CSRs is frequently cited as an explanation as to why poor and minority children are unrestrained, ${ }^{10}{ }^{12-14}$ no white drivers and only $4 \%$ of black drivers of inappropriately restrained
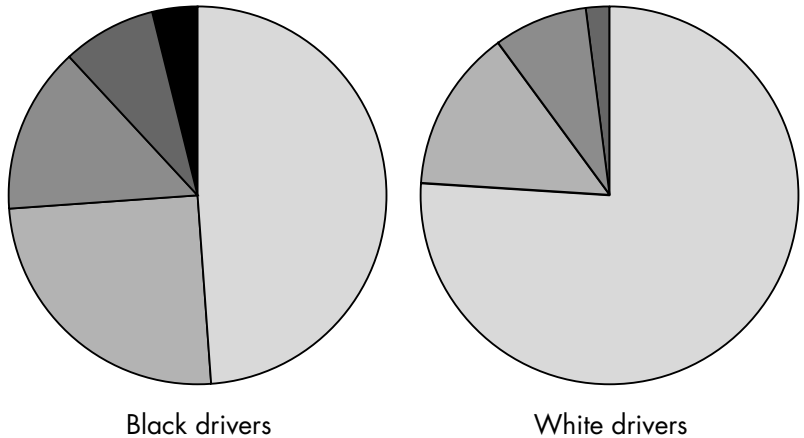

\begin{tabular}{|l}
$\square$ Child too large for booster \\
$\square$ Didn't know needed booster \\
Other \\
Child won't stay in booster \\
Can't afford booster
\end{tabular}

Figure 1 Driver perception of barriers to booster seat use $(n=114)$.

4-8 year olds cited cost of a booster seat as the reason for non-use.

There are a few limitations to this study. This study was conducted in a single state; thus results may not be generalizable to other populations. We sought to enhance generalizability by including three geographically dispersed urban communities in Tennessee. It is possible that the failure to cite cost as a barrier to CSR use reflected a higher income population; however the sample was obtained from an economically diverse population. Our definition of appropriate CSR use did not include correct attachment of the CSR to the vehicle, thus our results may be greater than other published studies of appropriate CSR use in which CSR installation was considered in determining correct usage. ${ }^{15}$

\section{CONCLUSIONS}

This study describes appropriate CSR use, and reported reasons for non-use by black and white child passengers. Future efforts to improve CSR use should focus on drivers of 4-8 year olds and drivers of black child passengers because

Table 2 Predictors of any and appropriate child safety restraint use for white and black child passengers*

\begin{tabular}{|c|c|c|c|c|}
\hline \multirow[b]{2}{*}{ Variable } & \multicolumn{2}{|c|}{ Any restraint use $\dagger$} & \multicolumn{2}{|c|}{ Appropriate restraint useł } \\
\hline & Adjusted RR & $95 \% \mathrm{Cl}$ & Adjusted RR & $95 \% \mathrm{Cl}$ \\
\hline \multicolumn{5}{|c|}{ White child passengers, $n=244$} \\
\hline \multicolumn{5}{|c|}{ Child age (years) } \\
\hline$<4$ & Reference & & Reference & \\
\hline $4-8$ & 0.91 & $0.86,0.96$ & 0.35 & $0.27,0.47$ \\
\hline $9-10$ & 0.85 & $0.74,0.98$ & 0.94 & $0.76,1.16$ \\
\hline \multicolumn{5}{|c|}{ Driver restrained } \\
\hline No & Reference & & Reference & \\
\hline Yes & 1.28 & $1.06,1.56$ & 1.74 & $1.02,2.95$ \\
\hline \multicolumn{5}{|c|}{ Black child passengers, $n=204$} \\
\hline \multicolumn{5}{|c|}{ Child age (years) } \\
\hline$<4$ & Reference & & Reference & \\
\hline $4-8$ & 0.81 & $0.71,0.91$ & 0.29 & $0.20,0.43$ \\
\hline $9-10$ & 0.98 & $0.89,1.06$ & 1.07 & $0.88,1.30$ \\
\hline \multicolumn{5}{|c|}{ Driver restrained } \\
\hline No & Reference & & Reference & \\
\hline Yes & 1.89 & $1.35,2.64$ & 1.77 & $1.03,3.02$ \\
\hline
\end{tabular}

*Poisson regression analysis using general estimating equations to account for clustering of child by vehicle. Model included child age and driver restraint use.

†Any restraint defined as: child passenger in any form of restraint device.

$\ddagger$ Appropriate restraint defined by age and weight criteria per Tennessee law. ${ }^{6}$

$\mathrm{RR}$, relative risk; $\mathrm{Cl}$, confidence interval.

Bold denotes statistical significance. 


\section{Key points}

- Children aged 4-8 years were frequently inappropriately restrained.

- Black children were more likely to be completely unrestrained than white children.

- Driver restraint use was associated with appropriate child safety restraint (CSR) use.

- Drivers of unrestrained 4-8 year olds incorrectly believed that their passengers were too large for a booster seat and many drivers lacked knowledge about the need for booster seat use.

- Efforts to improve CSR use should focus on drivers of 4-8 year olds and drivers of black child passengers.

these groups are at greatest risk of being unrestrained or inappropriately restrained. Educational efforts should address three specific aspects of booster seat use: driver knowledge about the need for booster seat use, the biometric requirements for appropriate booster seat use, and driver perceptions regarding the challenges of booster seat use.

\section{ACKNOWLEDGEMENTS}

The authors thank Safe Kids Coalitions in Memphis and Chattanooga, Tennessee and Washington, DC for assistance with data collection and processing.

\section{Authors' affiliations}

V L Gunn, W O Cooper, Department of Pediatrics, Child and Adolescent Health Research Unit, Division of General Pediatrics, Vanderbilt University School of Medicine, Nashville, TN, USA

R M Phillippi, Department of Pediatrics, Emergency Medical Services for Children, Division of Pediatric Critical Care, Vanderbilt University School of Medicine, Nashville, TN, USA

Competing interests: none.
Correspondence to: Dr V L Gunn, Department of Pediatrics, Child and Adolescent Health Research Unit, Vanderbilt University School of Medicine, AA-0216 MCN, 121521 st Avenue South, Nashville, TN 37232-2504, USA; veronica.gunn@vanderbilt.edu

Accepted 7 June 2005

\section{REFERENCES}

1 National Center for Injury Prevention and Control. Child Passenger Safety: Fact Sheet. 1 1/12/04. Available at http://www.cdc.gov/ncipc/factsheets/ childpas.htm (accessed November 2004).

2 National Center for Statistics and Analysis. Traffic safety facts, 2001, Washington, DC, 2002

3 Baker SP, Braver ER, Chen I, et al. Motor vehicle occupant deaths among hispanic and black children and teenagers. Arch Pediatr Adolesc Med 1998; 152:1209-12.

4 Mayrose J, Jehle DVK. An analysis of race and demographic factors among motor vehicle fatalities. J Trauma 2002;52:752-5.

5 Cody B, Mickalide A, Paul H, et al. Child passengers at risk in America: a national study of restraint use. Washington, DC: National SAFE KIDS Campaign, 2002.

6 New Child Restraint Law of 2003. Tennessee code. Vol 55-9-602, 2003.

7 Glassbrenner D, Carra JS, Nichols J. Recent estimates of safety belt use. J Safety Res 2004;35:237-44.

8 Keppel KG, Pearcy JN, Wagener DK. Trends in racial and ethnic-specific rates for the health status indicators: United States, 1990-1998, Healthy People statistical notes, no 23. Hyattsville, Maryland: National Center for Health Statistics, January, 2002.

9 Will KE, Geller ES. Increasing the safety of children's vehicle travel: from effective risk communication to behavior change. J Safety Res 2004; 35:263-74.

10 Lee JW, Fitzgerald K, Ebel BE. Lessons for increasing awareness and use of booster seats in a Latino community. Inj Prev 2003;9:268-9.

11 Simpson EM, Moll EK, Kassam-Adams N, et al. Barriers to booster seat use and strategies to increase their use. Pediatrics 2002;110:729-36.

12 Apsler R, Formica SW, Rosenthal AF, et al. Increases in booster seat use among children of low income families and variation with age. Inj Prev 2003;9:322-5.

13 Rivara FP, Bennett EE, Crispin B, et al. Booster seats for child passengers: lessons for increasing their use. Inj Prev 2001;7:210-13.

14 Hendrie D, Miller TR, Orlando $M$, et al. Child and family safety device affordability by country income level: an 18 country comparison. Inj Prev 2004; 10:338-43.

15 Stepanski BM, Ray LU. Booster seats: A community based study of installation and use by parents and caregivers. 45th Annual Proceedings of Assoc for Advancement of Automotive Medicine, September 24-26, 2001:37-48

\section{1 th European Forum on Quality Improvement in Health Care}

26-28 April 2006, Prague, Czech Republic

For further information please go to: www.quality.bmipg.com

Book early to benefit from a discounted delegate rate 